\title{
2215 鉄道車両の衝突安全性向上に対する構造最適化 Structural Optimization for Improvement of Train Crashworthiness
}

\author{
○奥 徳一郎 (早大院) 正 山川 宏（早大）鈴木 康文（JR 総研） \\ 舟津＼cjkstart浩二（JR 総研）＼cjkstart宇治田＼cjkstart寧（Imperial College, London, UK）
}

\begin{abstract}
Despite a recent need for the improvement of train crashworthiness, few design methods have been proposed. To establish it, we tried to introduce the concept of "Crushable body structure" to the design of train bodies in the past reports. There a train car with crushable zone was modeled by nonlinear spring and mass systems. Here we adopted a closer nonlinear spring and mass model to the real structure, and propose a method to determine the optimized structure of the train. We also considered an optimization problem by using the same model. Then we solve the problem by two different optimization methods and find strengths. of nonlinear spring in the crushable zones as to minimize the maximum decelerations evaluated in the center of the gravity of the train. We use 1-car train model and 2-cars train model to compare the results. In several numerical examples, it is seen impact decelerations were reduced, and passenger zones could be maintained enough spaces not to injure passengers by the proposed method.
\end{abstract}

\section{1. 緒言}

最近では鉄道車両の重大事故は年々減少傾向に転じてい るが, 列車衝乫事故は発生すると重大な被害をもたらす危険 性がある.そこで, 衝突事故が発生した際に車両内部の乗客・ 乗員の安全性が確保される車両構造を有する鉄道車両を車 両設計の段階で導入する必要性が指摘されている. 現状にお いて鉄道車両分野では自動車分野と比較した場合に，実車両 を用いた衝突試験を行う際に費用や規模などの面で不利な 点があり，鉄道分野で十分な安全設計基淮が確立されている とは言い難い，そこで，筆者らは鉄道車両を質量と非線形バ ネでモデル化をして, 自動車分野で使用されるクラッシャブ ルボディの概念を鉄道車両に導入することで, 衝突時に発生 する衝撃を吸収し乗員·乗客の安全性確保を図る一連の研究 を行ってきた(1)-(3). 本研究では従来の研究より実際の構 造に近い質量一非線形バネモデルを構筑してクラッシャブ ルゾーンと生存空間の概念を導入して生存空間での安全性 を確保するための構造最適化を行った. 具体的には生存空間 を乗員空間と乗客空間に分類され, 両空間の間にクラッシャ ブルゾーンを導入し, クラッシャブルソーンのバネの非線形 特性に対する最適化を行った.この際最適化の評価手法とし て, 衝突時に発生する車両重心での減速度の最大值の最小化 を図った. 特に本研究では 1 車両と 2 車両での両方の解析を 行うことで, 1 車両モデルと 2 車両モデルにおける安全設計 の相違点について比較・検討を行った.

\section{2. 解析モデル}

鉄道車両衝突時の破壊現象は主に材料の圧縮特性や板部 の面外塑性座屈, 塑性崩壊などに依存する. 本研究では従来 の一連の研究と同様に鉄道車両のモデル化を行う際に非線 形バネー集中質量系モデルを用いてこれらの現象を近似的 に再現した. また解析モデルでのバネの非線形特性は実車両
試験で得られた圧縮破壊特性に関するデータを基に決定し ており，実際のテータは図 1 に示す通りである.
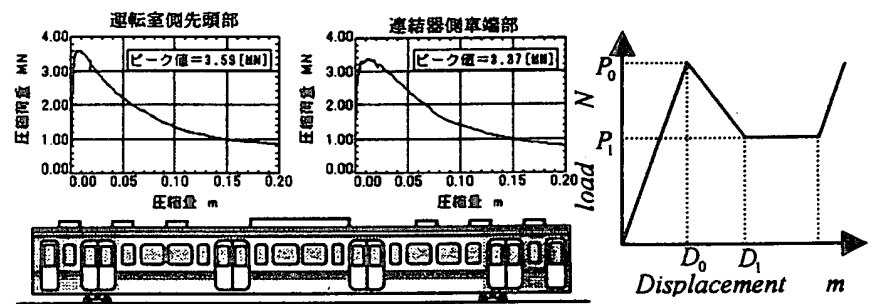

Fig. 1 nonlinear spring used in modeled-train 本研究では特にモデル化の際に実車両に近いモデルを考慮 するために車両部分の枠組に着目して端梁, 枕梁, 側梁, 中 梁に対して集中質量とバネを図 2 のように配置した.
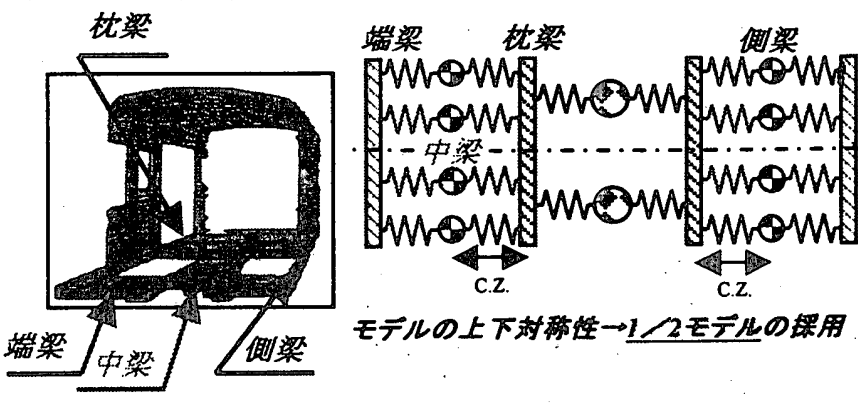

モデルの上下㳔称性 $\rightarrow 1 / 2$ モデルの婇用

Fig. 2 model of analysis

モデルの車両の全長は $20[\mathrm{~m}]$ であり, 車両部分の前後端の 1.3 [m]を乗員空間とし, 中心部分の 16.2 [m] を乗客空間 として乗員空間と乗客空間の間の 0.6 [m] をクラッシャブ ルゾーンとしている. また 2 車両モデルでは中間に $0.75[\mathrm{~m}]$ の連結器を設け, 連結器部分でも衝㼫を吸収させた。この部 分で衝撃を吸収することで乗員・乗客空間の大変形が生じな いような構造を目標とする. 連結器の特性値を設計変数にと り衝撃の吸収を図ることで, クラッシャブルソーンを最適化 した際との比較を行った. 


\section{3. 最適化手法}

\section{1. 鉄道車両衝突時における動的応答解析}

本研究では解析条件として剛体壁に $25[\mathrm{~km} / \mathrm{h}]$ で衝突し た場合を想定した. 車両衝突時の動的解析はバネ一質量系の 車両モデルを行列形式の運動方程式で表し，その運動方程式 の解を逐次積分法である Newmark の $\beta$ 法を用いて求め，時系 列に対する変位・速度・加速度を算出した．動的解析で用い る時間の增分幅は 1 車両モデルでは $5.0 \times 10^{-5}$ 秒， 2 車両モデ ルで $1.0 \times 10^{-5}$ 秒とした. また解析時間幅は 1 車両モデルでは 0.15 秒まで， 2 車両モデルでは 0.60 秒までとする. 特に加 速度成分を解析する際に高周波成分は大局的には衝突安全 性に寄与しないと見なし $20[\mathrm{~Hz}]$ 以上の成分を除去した加 速度で評価を行った。

\section{2. 䘖突安全性に対する棬造最適化}

本研究では鉄道車両の安全性を確保するために車両重心 の最大減速度を最小化する構造最適化を行う.構造最適化で の設計変数はクラッシャブルゾーンの非線形バネ特性の非 線形特性值とし，具体的には図. 1 の P0, P1，D0，D1 の諸值 をとった. 目的関数は衝突時に生じる車両重心の最大减速度 をとった. 2 車両連結時は各車両の車両重心の最大減速度に 重み係数を乗じたもの（Min $\left.f=\sum w_{i} \ddot{x}_{i}\right)$ を目的関数とし， 各車両の重み係数を 0.5 とした. また構造最適化の手法とし て GA（遗伝的アルゴリズム）を用いた．実際に安全性確保 の面で乗客空間が大変形を起こすと乗客に被害が及ぶため, 形状変形をなるべく避けるような構造が好ましく, 動的応答 解析の際に車両要素の変形量も計算した.

\section{4. 解析結果}

\section{1. 1 車両モデルの解析例}

1 車両モデルの解析では, 車両構造の最適化の際に設計の 改善幅の大きい設計変数の組み合わせを求めた. 設計変数に は非線形バネの特性值（P0，P1，D0，D1）を選択することで， 組み合わせを考えた。

Tablel Numerical results for 1 car-model

\begin{tabular}{|c|c|c|}
\hline 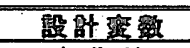 & 圆的閶盗 $\left(\mathrm{m} / \mathrm{s}^{3}\right)$ & 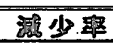 \\
\hline 初腉檤 & $1.433 \times 10^{2}$ & \\
\hline $\mathbb{P O}-\mathbb{D O}$ & $7.402 \times 10^{\prime}$ & $48.34 \%$ \\
\hline $\mathbb{P O}-\mathbb{D} \mathbb{1}$ & $7.477 \times 10^{1}$ & $47.82 \%$ \\
\hline $\mathbb{P Q}$ - P1 & $7.135 \times 10^{1}$ & $50.20 \%$ \\
\hline $\mathbb{P} \mathbb{1}-\mathbb{D} 0$ & $1.334 \times 10^{2}$ & $6.930 \%$ \\
\hline $\mathbb{P} \mathbb{I}-\mathbb{D} \mathbb{I}$ & $1.342 \times 10^{2}$ & $6.365 \%$ \\
\hline$\overline{P O-D Q-D \mathbb{1}}$ & $7.313 \times 10^{1}$ & $48.96 \%$ \\
\hline $\mathbb{P Q} \mathbf{P} \mathbb{1 - \mathbb { D O }}$ & $6.697 \times 10^{1}$ & $53.26 \%$ \\
\hline $\mathbb{P Q} \mathbf{P} \mathbb{1}-\mathbb{D} 1$ & $6.928 \times 10^{1}$ & $511.64 \%$ \\
\hline $\mathbb{P 1 - \mathbb { D 0 } 0 - \mathbb { D } 1}$ & $1.268 \times 10^{2}$ & $11.50 \%$ \\
\hline$P 0-\mathbb{P 1 - D 0 - D \mathbb { 1 }}$ & $6.584 \times 10^{1}$ & $54.05 \%$ \\
\hline
\end{tabular}

表 1 で表されるように，P0（非線形バネ要素のピーク値） を設計変数に含まない場合において目的関数の減少率が 6. $365 \%$ 1 $1.50 \%$ であるのに対して，P0 を設計変数に含む 場合では目的関数の減少率は $47.82 \%$ 54.05\%となり, 目 的関数の减少幅が大幅に改善されることが判明した. 特にこ の場合は衝突直後に発生する減速度の最大值が減少してい ることが分かった．従って，1 車両モデルの場合はPOを設 計変数に含むことで椪造最適化の効率が改善され安全性が 向上することを確認した

\section{2. 2 車両モデルの解析例}

1 車両モデルにおいて PO が最適化に大きく寄与すること
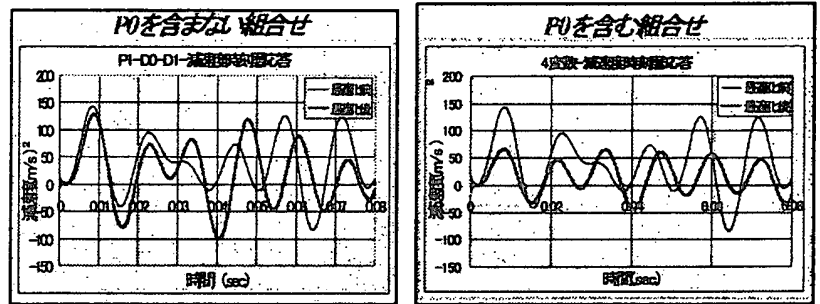

Fig. 3 Effect of P0 on optimization result が判明した. 2 車両モデルの解析では連結器部分とクラッシャ ブルゾーン部分を独立的な設計変数とし, 連結器のみ（パター ン 1), クラッシャブルゾーンのみ (パターン 2), 連結器+クラ ッシャブルゾーン（パターン 3) を設計変数にとる場合におい て計算を行った. 設計変数の組み合わせは 1 車両モデル解析の 結果よりP0を含む組み合わせを選択した.

Table2 Numerical results for 2cars-model

\begin{tabular}{|c|c|c|c|}
\hline & 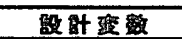 & 目的閐的 $\left(\mathrm{m} / \mathrm{s}^{2}\right)$ & 穿安案 \\
\hline . & 彻期解 & $1.644 \times 10^{2}$ & \\
\hline \multirow{4}{*}{ 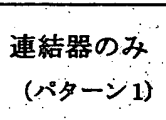 } & PO-PI & $7.911 \times 10^{1}$ & $51.87 \%$ \\
\hline & P0-P1-DO & $7.462 \times 10^{1}$ & $54.61 \%$ \\
\hline & P0-P1-D1 & $7.841 \times 10^{1}$ & $52.30 \%$ \\
\hline & P0-P1-D0-D1 & $7.326 \times 10^{1}$ & $55.44 \%$ \\
\hline \multirow{4}{*}{$\begin{array}{l}\mathrm{CZ} \text { のみ } \\
\text { (パターン 2) }\end{array}$} & PO-P1 & $6.471 \times 10^{1}$ & $60.63 \%$ \\
\hline & PO-P1-DO & $6.348 \times 10^{1}$ & $61.38 \%$ \\
\hline & P0-P1-D 1 & $6.047 \times 10^{1}$ & $63.21 \%$ \\
\hline & P0-P1-D0-D1 & $5.818 \times 10^{1}$ & $64.62 \%$ \\
\hline \multirow{4}{*}{$\begin{array}{l}\text { 連結器+CZ } \\
(\text { パターン 3) }\end{array}$} & P0-P1 & $4.684 \times 10^{t}$ & $71.51 \%$ \\
\hline & P0-P1-D0 & $5.370 \times 10^{1}$ & $67.34 \%$ \\
\hline & PO-P1-D1 & $4.7 .91 \times 10^{1}$ & $70.85 \%$ \\
\hline & P0-P1-D0-D1 & $4.835 \times 10^{1}$ & $70.59 \%$ \\
\hline
\end{tabular}

図 2 で示されるように，パターン1の目的関数の减少率は $51.87 \%$ ～55. 45\%程度であり先頭車両運転台部分のクラッシ ヤブルゾーンの一部と連結器部分で圧壊や塑性変形が見られ た. パターン 2 の目的関数の減少率は $60.63 \%$ 64. 62\%程度 であり, パターン 1 で圧壊した部分に連結器付近のクラッシャ ブルゾーンで塑性変形が生じた. 最後にパターン 3 の目的関数 の減少率は $67.34 \%$ 71.51\%であり, パターン 2 と比較しても 圧買部分が増えて効率良く衝眮を吸収出来ることが判明した。

5. 結言

1. 実車両に比較的近い非線形バネ一集中質眮系モデルを利用し て時刻暦応答量及び要素変形量を求める手法を示した.

2. 鉄道車両の 1 車両モデルと 2 車両モデルの構造最適化計算を 行ったことで最適化手法を示し両者を比較・検討した

3. 1 車両モデルでは P0（非線形バネ要絮の最大荷重）を設計 変数にとることで最適化結果が良好であることを示した。

4. 2 車両モデルにおいて連結器と C. Z. を. を独立的に最適化し バネ要素の変形状態から車両構造の压蛽の様子を示した. その 結果, 両者の比較から効率の良い最適化が行えた。

6. 参考文献

（1）. 筒井，山川，宇治田，鈴木，「鉄道車両の衝突安全性向上 に対する構造最適化」, 日本機械学会第 75 期通常総会講演会講 演論文集 (IV)，1998，432－433

(2). 筒井, 山川, 宇治田, 鈴木, 「鉄道車両の衝突安全性向上 に対する構造最適化」，日本機会学会'99 講演論文集（B）, $135-138$

（3）、篠生，山川，宇治田，鈴木，「鉄道車両の衝突安全性向上 に対する構造最適化」, 日本機械学会第 77 期通常総会輞演会犝 演論文集 (IV)，2000，207-208 